\title{
A Systematized Literature Review: Defining and Developing Engineering Competencies
}

\section{Mr. Hossein Ebrahiminejad, Purdue University}

Hossein Ebrahiminejad is a graduate research assistant at SPHERE(Social Policy and Higher Education Research in Engineering), and a Ph.D. student in Engineering Education at Purdue University. He completed his M.S. in Biomedical Engineering at New Jersey Institute of Technology (NJIT), and his B.S. in Mechanical Engineering in Iran. His research interests include student pathways, educational policy, and relationships between education and professional practice. 


\title{
A Systematized Literature Review: Defining and Developing Engineering Competencies
}

\begin{abstract}
Essential competencies have been identified for engineers working in industry. These competencies include (but are not limited to) critical thinking, problem-solving, teamwork, and communication. Engineering education research has shown however, that engineering undergraduate students often fail to develop these crucial competencies. Industry has also noted that recent graduates exhibit competency gaps. To address these gaps, it is important for higher education institutions to seek to understand the competencies identified as necessary in industry. Moreover, one could argue educational institutions should develop and assess students' competencies based on these professional demands.

This research systematically reviews literature related to this topic. This review seeks to answer two questions: 1) What are the competencies engineering students must have to be successful in the world of practice? 2) How can engineering education help students to develop these competencies? A total of 30 articles were identified as relevant and reviewed. Two themes were applied: 1) Identification of engineering competencies 2) Approaches to address competency shortfalls. Review of the literature suggests that while educational institutions are mostly aligned with engineering competencies hailed as important to ABET, there is still room to improve. The most frequent competencies mentioned in the literature include communication skills, teamwork, and problem-solving skills. Results suggest developing a continuous improvement mindset will encourage both educators and their institutions to include stakeholders such as industry into account as they systematically assess and review their graduating engineering students and undergraduate programs. Further, to date there does not appear to be a single accepted approach or best practice for incorporating targeted competencies into engineering curricula.
\end{abstract}

\section{Introduction}

Competency is defined as "... a cluster of related knowledge, attitudes, and skills that affect a major part of one's job (i.e. one or more key roles or responsibilities); that correlates with performance on the job; that can be measured against well-accepted standards; and that can be improved via training and development ${ }^{1}$ (p. 60)". Thus, competencies are directly related to job performance. A better understanding of "engineering competency", necessarily involves the investigation of competencies engineers need to perform in settings such as industrial practice. Engineering competencies can be categorized into three categories; competencies related to 1) engineers' behaviors, 2) skills and techniques, and 3) manager-described competencies ${ }^{2}$.

Multiple studies have focused on the gaps between engineering competencies gained during academic years and those needed in the industry ${ }^{3-6}$. This is a relevant and important area of research in engineering education particularly, as it is sometimes forgotten that industry is the destination of most of the world's engineers, not academia ${ }^{7}$. On the other hand, more recent papers suggest that academia and industry are more aligned than in the past in terms of secondary institution's development of students' preparatory skills for practice, and industry's approval of their appropriate level of readiness ${ }^{8}$. Yet, while industry continues to be satisfied 
with the technical and scientific abilities of graduate engineers, they retain a "marked lack of satisfaction" with their non-technical capabilities".

In the last three decades, industry has focused efforts to more proactively address these perceived gaps. For example, Boeing created a list of "Desired Attributes of an Engineer", for which the primary purpose was to begin a dialogue with the academy regarding industry needs associated with incoming graduates ${ }^{10}$. Alternatively, academia had already began taking note of industrial concerns, evidenced by a reform movement in engineering education, which was launched almost a decade prior $^{11}$.

Engineering education agencies around the globe have also define frameworks and guidelines for engineering educators and schools to articulate and monitor the engineering competency development in their programs. These organizations include the Accreditation Board of Engineering and Technology $(\mathrm{ABET})^{12}$, Engineers Australia (EA) ${ }^{13}$, and the Canadian Engineering Accreditation Board (CEAB) ${ }^{14}$. As an example, ABET's current focus for institutions to follow in undergraduate engineering programming includes: engineering knowledge; problem analysis; design/development of solutions; investigation \& experimentation; modern tool usage; engineers and society; environment and sustainability; ethics; individual and teamwork; communication; project management and finance; and lifelong learning ${ }^{15}$. Guidelines to assess these (or similar) competencies are created within each of the oversight organizations. The overarching purpose of these guidelines is to aid in the relevance and technical strength of engineering students' preparation for professional practice. Subsequently, educators and researchers globally have applied the recommended guidelines and assessment frameworks to gauge development of targeted competencies among the student population.

In spite of the many opinions around what competencies engineers should possesses to meet some standard of engineering practice, there appears to be some disconnect between governing organizations, educational institutions, industry and ultimately students' ability to demonstrate "ideal" competencies in their performed engineering work. Through the use of this comprehensive literature review, I will explore and accumulate the related research to help codify a unified response around what competencies are considered desirable, and further how engineering education can help students develop these targeted competencies.

\section{Methods}

This systematized literature review follows a sequential procedure. The step-wise procedure used here ensures a robust and repeatable process for others to replicate ${ }^{16}$. To ensure a broad search, engineering and education databases were selected to search for relevant articles on past and current research around the topic of engineering competencies.

Multiple keywords and specific search logic were deployed for this search as follows: "engineering"; "competency" OR "talent" OR "skill" OR "graduate attributes" and "industry" OR "practice." These keywords were searched both in the abstract and subject line of the articles, individually and in combination. The date of each search, the database search, the coverage of the literature for each database explored and the number of articles found is recorded in Table 1. 
Table 1

Search details for databases used

\begin{tabular}{|l|l|l|c|}
\hline Database & $\begin{array}{l}\text { Date of } \\
\text { Search }\end{array}$ & Database Coverage & $\begin{array}{c}\text { Number of } \\
\text { Articles }\end{array}$ \\
\hline ERIC & $10 / 15 / 2016$ & $\begin{array}{l}\text { A complete collection of abstracts and citations of } \\
\text { peer-reviewed literature }\end{array}$ & 171 \\
\hline Compendex & $10 / 15 / 2016$ & Articles in engineering and related disciplines & 74 \\
\hline $\begin{array}{l}\text { Education } \\
\text { Source }\end{array}$ & $10 / 15 / 2016$ & $\begin{array}{l}\text { The most thorough collection of full-text } \\
\text { education journals and scholarly research }\end{array}$ & 23 \\
\hline
\end{tabular}

To select the articles for review, four criteria were used. The articles collected from the search must: 1) be of high quality, meaning having been peer-reviewed, 2) describe an empirical study (i.e. rather than a literature review), 3) were conducted in the context of higher engineering education, and 4) consider industry needs or perspectives in some way.

Searching with the keywords in the targeted indexes provided 267 possible articles of interest, excluding duplicates. Of the 267 articles, 198 were excluded as unrelated based on their title. The inclusion criteria was then applied to the abstracts of the 69 remaining articles. During this process, another 29 articles were removed from the selection. After examining the full-text of the 40 remaining articles, a yield of 23 articles were available for extensive analysis.

The 23 closely reviewed articles were then placed into one of two main themes/classifications in order to answer the research questions. The first classification represented articles whose aim was to identify the essential competencies that should be developed through an engineering education, and the second theme of articles tended to define approaches for implementing these competencies into education based curriculum or programming.

\section{Results}

The following paragraphs elaborate upon the literature and each article's relative positioning in the themes focused on responding to the research questions in this paper.

\section{Theme 1: What are engineering Competencies?}

Five of the 23 articles were appropriate for the first theme, looking to identify essential engineering competencies. Among the five, three articles listed what the authors expressed as the necessary competencies for engineering jobs ${ }^{3,5,17}$. Among the competency lists presented by these studies, some common competencies are identified. The common competencies include written and oral communication ${ }^{3,5,17}$, teamwork and capacity for co-operation ${ }^{3,17}$, and adaptability (or ability to cope with work pressure and stress) ${ }^{3,17}$. Ivanova ${ }^{17}$ also mentioned networking as an important engineering competency, but no other articles referred to anything 
comparable as a potential competency. Nair, et al. ${ }^{3}$ offered additional competencies to consider including: a. Interpersonal skills with colleagues and clients, b. Capacity to analyze and solve problems, c. Ability to develop new or innovative ideas, directions, opportunities or improvements, $\mathrm{d}$. Time management skills, e. ability to apply knowledge in the workplace and $\mathrm{f}$. capacity to learn new skills.

Beyond listing or prioritizing competencies, often the articles within this theme aimed to categorize the competencies of importance. While the categories themselves vary, the studies share a number of common categories. McMaster ${ }^{10}$ in particular categorized the competencies they chose to highlight as foundational technical skills, professional skills, engineering skills, and business skills/acumen. Each are presented and defined as follows:

1. Foundational technical skills: math and science analysis and computing

2. Professional skills: communication, teamwork, networking, and interpersonal

3. Engineering skills: design and system integration

4. Business skills and acumen: cost accounting, scheduling, and planning

Using these categories offered a simplifying strategy for presenting all of the literature reviewed in this study, from both themes. Results are shown in table 2.

Although articles in this theme do not attempt to elaborate upon how these necessary competencies should be taught or applied within the engineering curricula, they did all reflect an attitude that the reform of engineering curricula is a work in process that should continue, sometimes offering a proposed categorized list of competencies which they felt could bridge the transition between academia and industry ${ }^{10}$.

\section{Theme 2: Approaches to Address Competency Shortfalls}

The remaining eighteen articles (an overwhelming majority of all examined articles) were classified into the second theme. This theme of articles discuss how student's engineering practice competencies can be addressed and/or developed. Approaches toward competency development occurring in this theme were categorized (as mentioned in theme one), using the simplifying McMaster ${ }^{10}$ skill category framework: 1) foundational technical skills, 2) professional skills, 3) engineering skills, and 4) business skills and acumen.

Articles in this theme tended to focus on addressing the development of a single competency, rather than approaching development holistically across competencies. Each author makes the case with evidence for why the competency highlighted within their article is crucial for engineering students. Table 2 summarizes articles included in this theme and their approach(es) for developing the competency they implemented in each research study.

A review of table 2 reveals that multiple authors ${ }^{18-25}$ (eight articles) of the eighteen articles focused on development of professional skills, including interview skills, globalization, leadership, teamwork, and communication competencies. Likewise, multiple authors (eight articles) were interested in developing Engineering skills such as critical thinking, engineering design, and problem-solving ${ }^{26-33}$. Interestingly, among the reviewed articles, only two articles were interested in developing foundational and technical skills ${ }^{34,35}$. Surprisingly, none of the articles discussed the need for engineers to develop business skills or related acumen, in spite of the fact that related competencies are noted as important to $\mathrm{ABET}^{12}$. Also interesting is that the articles mentioned in this theme referenced the formation of competency development through a 
wide variety of settings and contexts. These formal and informal settings ranged from adding a series of courses into engineering curricula to developing competencies through service learning (see table 2). 
Table 2

\begin{tabular}{|c|c|c|c|c|}
\hline Author & $\begin{array}{l}\text { Competency } \\
\text { Category }\end{array}$ & Competency & $\begin{array}{l}\text { Implementation } \\
\text { Approach }\end{array}$ & Approach Used \\
\hline Nelson ${ }^{18}$ & Professional Skills & Interview Skills & Service Learning & $\begin{array}{l}\text { Real world project using service learning ( Engineering Projects in Community } \\
\text { Service -EPICS) }\end{array}$ \\
\hline Plumblee Ii, et al. ${ }^{19}$ & Professional Skills & Globalization & Service Learning & $\begin{array}{l}\text { The article develops student organization. The experience help in fostering } \\
\text { globalization through projects done in developing countries. Other competencies } \\
\text { such as teamwork, communication and leadership will be also fostered along with } \\
\text { this experience. }\end{array}$ \\
\hline $\begin{array}{l}\text { Allan and Chisholm } \\
20\end{array}$ & Professional Skills & Globalization & Teaching Model & A model is proposed to educate educators on how to teach global competencies. \\
\hline Lohmann, et al. ${ }^{21}$ & Professional Skills & Globalization & $\begin{array}{l}\text { Teaching and } \\
\text { Assessment Model }\end{array}$ & $\begin{array}{l}\text { The article presents a conceptual model and curriculum model to foster } \\
\text { global competencies. They also present an assessment model to } \\
\text { determine if students gained the competencies. }\end{array}$ \\
\hline Sankar, et al. ${ }^{22}$ & Professional Skills & Leadership & Pedagogical Tool & $\begin{array}{l}\text { The article used a variety of methods to enhance leadership skills. They } \\
\text { concluded that "The use of projects and multi-media case studies was perceived } \\
\text { as valuable in enhancing the learning experiences and attitude toward engineering } \\
\text { (p.34)". }\end{array}$ \\
\hline $\begin{array}{l}\text { Davies and } \\
\text { Rutherford }{ }^{23}\end{array}$ & Professional Skills & Teamwork & $\begin{array}{l}\text { Project Based } \\
\text { Learning }\end{array}$ & $\begin{array}{l}\text { In this research Civil Engineering students are grouped in teams including } \\
\text { fulltime students as mentees and at least one part time student working in the } \\
\text { workplace as mentors. }\end{array}$ \\
\hline Ulijn, et al. ${ }^{24}$ & Professional Skills & Communication & Course Design & By role playing a simulated real-world situation. improved students' competency \\
\hline Rouvrais, et al. ${ }^{25}$ & Professional Skills & Communication & $\begin{array}{l}\text { Project-Based } \\
\text { Learning } \\
\text { Framework }\end{array}$ & $\begin{array}{l}\text { This was added to engineering students' coursework over four semesters. } \\
\text { Each semester required group work on a competency-controlled project. }\end{array}$ \\
\hline Pierce, et al. ${ }^{26}$ & Engineering Skills & Critical Thinking & $\begin{array}{l}\text { Pedagogical } \\
\text { Framework }\end{array}$ & $\begin{array}{l}\text { This research uses a pedagogical framework (EFFECT) to foster effective critical } \\
\text { thinking in geotechnical engineering students. }\end{array}$ \\
\hline Welch, et al. ${ }^{27}$ & Engineering Skills & Critical Thinking & $\begin{array}{l}\text { Pedagogical } \\
\text { Framework }\end{array}$ & $\begin{array}{l}\text { The article implemented a framework called Paul-Elder framework into an } \\
\text { engineering introductory course to foster critical thinking. }\end{array}$ \\
\hline
\end{tabular}




\begin{tabular}{|c|c|c|c|c|}
\hline Author & $\begin{array}{l}\text { Competency } \\
\text { Category }\end{array}$ & Competency & $\begin{array}{l}\text { Implementation } \\
\text { Approach }\end{array}$ & Approach Used \\
\hline Strong 28 & Engineering Skills & $\begin{array}{l}\text { Engineering } \\
\text { Design }\end{array}$ & Course Design & $\begin{array}{l}\text { An elective series of courses known as the Multidisciplinary Design Stream } \\
\text { (MDS) was introduced which students worked in multi-disciplinary teams to } \\
\text { enhance students' design, professional, and problem solving skills. }\end{array}$ \\
\hline Weilerstein, et al. ${ }^{29}$ & Engineering Skills & $\begin{array}{l}\text { Innovation and } \\
\text { Entrepreneurship }\end{array}$ & $\begin{array}{l}\text { Informal } \\
\text { Scaffolding }\end{array}$ & $\begin{array}{l}\text { This research shows how creating informal settings such as course grants, } \\
\text { students' entrepreneurship team grants, and entrepreneurship competitions as can } \\
\text { improve engineering students Innovation and Entrepreneurship skills }\end{array}$ \\
\hline Heylen, et al. ${ }^{30}$ & Engineering Skills & Problem Solving & Course Design & $\begin{array}{l}\text { A course called 'Problem Solving and Engineering Design' is introduced to } \\
\text { enhance problem solving in first year engineering students. }\end{array}$ \\
\hline Waller and Kaye ${ }^{31}$ & Engineering Skills & Problem Solving & Course Design & $\begin{array}{l}\text { A three month course in problem solving, modeling and simulation was designed } \\
\text { for nuclear engineering students. This course was taught by instructors from both } \\
\text { industry and academia. }\end{array}$ \\
\hline $\begin{array}{l}\text { Shawcross and } \\
\text { Ridgman }^{32}\end{array}$ & Engineering Skills & Problem Solving & $\begin{array}{l}\text { Development } \\
\text { Framework }\end{array}$ & $\begin{array}{l}\text { The aim of this research was to construct a development framework using } \\
\text { literature and testing it by evaluating the development of problem solving. }\end{array}$ \\
\hline Teng, et al. ${ }^{33}$ & $\begin{array}{l}\text { Engineering } \\
\text { Skills }\end{array}$ & $\begin{array}{l}\text { Problem } \\
\text { Solving }\end{array}$ & Coop & $\begin{array}{l}\text { A model is introduced to enhance students' engineering skills in the informal } \\
\text { setting (factory) }\end{array}$ \\
\hline Flegg, et al. ${ }^{34}$ & $\begin{array}{l}\text { Foundation and } \\
\text { Technical Skills }\end{array}$ & $\begin{array}{l}\text { Mathematical } \\
\text { Thinking }\end{array}$ & Course Design & $\begin{array}{l}\text { The article focused on how students viewed relevance of the mathematical } \\
\text { thinking they learned in a first-year engineering mathematics course. }\end{array}$ \\
\hline Gainsburg ${ }^{35}$ & $\begin{array}{l}\text { Foundation and } \\
\text { Technical Skills }\end{array}$ & $\begin{array}{l}\text { Mathematical } \\
\text { Modeling }\end{array}$ & Case Study & $\begin{array}{l}\text { The research focused on different student perceptions of mathematical modeling } \\
\text { and its impact on engineering education. }\end{array}$ \\
\hline
\end{tabular}




\section{Discussion}

This systematized literature review intends to answer the extent to which current research responds to two research questions. First, what are the competencies engineering students must have to be successful in the world of practice, and second, how can engineering education help students to develop these competencies now sometimes considered gaps? The clear occurrence of themes among the reviewed articles helps us address these questions. To begin, one common conclusion of all the research presented here was the necessity for ongoing reform in engineering education curricula, which suggests the importance of this subject and the responsibility of engineering educators, educational programs, and oversight organizations focused on maintaining high and consistent quality across all educational institutions. Additionally, the competencies mentioned in the reviewed articles were mostly aligned with accreditation boards (e.g. ABET) and the 2020 National Engineering Reports ${ }^{36}$. The most frequent attributes mentioned in these articles were competencies such as communication skills, teamwork, and problem-solving skills.

Based on the research questions that drove the two themes for this literature review, some of the literature recommended ways to implement the competency within an engineering curriculum. This seems to be an interesting finding, as some might suggest that since the accrediting bodies have determined the competencies of most importance, the argument over which competencies to prioritize and highlight is over. This can be somewhat demonstrated by an obvious research gap in recent years related to the research questions.

Although more than two hundred articles were found in the initial database search database, only five of the applicable papers (out of 23) were published in the last four years. Yet, the apparent debate within engineering education research literature suggests the issue remains unsettled, and there exists an opportunity for ongoing review and continuous improvement, in particular, incorporating the perspectives of industrial practice. Further, there also appears to be room to develop additional frameworks for improved integration and implementation into engineering programs. For instance, frameworks and designed courses mentioned in reviewed papers focus on one competency, these frameworks and courses can be modified and redesigned in a way to cover multiple curtail competencies.

Reviewed articles show the limited number of studies focusing on foundation and technical skills (two articles out of 18) and business skills (no articles). This finding, reveals that these two categories can be a subject for discussion for future investigation. Two questions should be answered: does the current engineering curricula cover these two categories? If not, how can these competencies be developed?

Last but not least, findings of this literature review suggest academic and industry perspectives are explored independently. I suggest that that in order to better address the gap between industry and academia, research should consider both perspectives concurrently, and look for collaborative opportunities to explore and test viewpoints, application of curricular improvements, etc, in a joint effort.

\section{Limitation}

This systematized literature review has several limitations. First, due to the limited search strings and databases used, some empirical studies may have been excluded from the review. Second, 
only three databases were queried to index the most relevant articles. This may have caused some relevant articles to not appear in the search results. Third, more than one hundred papers were excluded based on their titles. Since not every title provides an accurate indication of the article's key points, some related articles may have been excluded from consideration. Finally, only one researcher developed the search methods, and the corresponding interpretations may include the researcher bias based on his close proximity to the data analysis and categorization.

\section{Conclusion}

This paper reviews research addressing the necessary competencies required to prepare engineering students for the world of engineering practice. The following two themes emerged: 1) Identification of engineering competencies 2) Approaches to address competency shortfalls.

Review of the literature suggests that while educational institutions are mostly aligned with engineering competencies hailed as important to ABET, there is still room to improve. Results also suggest developing a continuous improvement mindset tool encourage both educators and their institutions to include stakeholders such as industry into account as they systematically assess and review their graduating engineering students and undergraduate programs. Further, to date there does not appear to be a single accepted approach or best practice for incorporating targeted competencies into engineering curricula. More research into how to address and incorporate targeted engineering competencies into undergraduate curricula is called for.

\section{Acknowledgement}

I acknowledge the contributions of Dr.Mary Pilotte.

\section{References}

1 Parry, S. B. Just What Is a Competency?(And Why Should You Care?). Training 35, 58 (1996).

2 Turley, R. T. \& Bieman, J. M. in ACM Conference on Computer Science. 271-278.

3 Nair, C. S., Patil, A. \& Mertova, P. p. m. a. m. e. a. Re-engineering graduate skills - a case study. European Journal of Engineering Education 34, 131-139, doi:10.1080/03043790902829281 (2009).

4 Watson, J. J. L. W. u. n. \& Lyons, J. L. s. e. Aligning Academic Preparation of Engineering Ph.D. Programs with the Needs of Industry. International Journal of Engineering Education 27, 1394-1411 (2011).

5 Rajai, M. \& Johnson, K. V. Creating New Engineers for the New Millennium. Industry \& Higher Education 15, 349-352 (2001).

6 English, V. Helping Students Build Their Future in Engineering. Education in Science, 18 (2014).

7 Todd, R. H., Sorensen, C. D. \& Magleby, S. P. Designing a senior capstone course to satisfy industrial customers. Journal of Engineering Education 82, 92-100 (1993).

8 Eggert, R. J. in ASEE Annual Conference and Exposition: Staying in Tune with Engineering Education. 1901-1912. 
9 Frise, P., Sirizzotti, M., Gaspar, R. \& Reader, G. in Annual Conference of the Canadian Society of Mechanical Engineers, Kingston, Ontario.

10 McMasters, J. Influencing Student Learning: An Industry Perspective. International Journal of Engineering Education 22, 447-459 (2006).

11 Jesiek, B. K., Newswander, L. K. \& Borrego, M. Engineering education research: Discipline, community, or field? Journal of Engineering Education 98, 39-52 (2009).

12 Accreditation Policy and Procedure Manual (APPM), 2017 - 2018|ABET, $<$ http://www.abet.org/accreditation/accreditation-criteria/accreditation-policy-andprocedure-manual-appm-2017-2018/> (2017).

13 Accreditation of Engineering Education Programs, $<$ https://www.engineersaustralia.org.au/About-Us/Accreditation> (2017).

14 Canadian Engineering Accreditation Board, 〈https://engineerscanada.ca/accreditation/accredited-programs> (2016).

15 Goel, S. Competency focused engineering education with reference to IT related disciplines: is the Indian system ready for transformation? Journal of Information Technology Education 5, 27-52 (2006).

16 Borrego, M., Foster, M. J. \& Froyd, J. E. Systematic literature reviews in engineering education and other developing interdisciplinary fields. Journal of Engineering Education 103, 45-76 (2014).

17 Ivanova, M. Social Competencies Identification for Realization of Successful Engineering Practice. Interactive Technology and Smart Education 9, 217-229 (2012).

18 Nelson, M. S. Teaching Interview Skills to Undergraduate Engineers: An Emerging Area of Library Instruction. Issues in Science and Technology Librarianship (2009).

19 Plumblee Ii, J. M., Cattano, C., Bell, L. \& Klotz, L. Fulfilling engineering program objectives through service learning campaigns in developing countries. Leadership and Management in Engineering 12, 46-52, doi:10.1061/(ASCE)LM.1943-5630.0000164 (2012).

20 Allan, M. \& Chisholm, C. U. Achieving Engineering Competencies in the Global Information Society through the Integration of On-Campus and Workplace Environments. Industry and Higher Education 22, 145-152 (2008).

21 Lohmann, J. R., Rollins, H. A. \& Hoey, J. J. Defining, Developing and Assessing Global Competence in Engineers. European Journal of Engineering Education 31, 119-131 (2006).

22 Sankar, C. S., Kawulich, B., Clayton, H. \& Raju, P. K. Developing Leadership Skills in "Introduction to Engineering Courses" through Multi-Media Case Studies. Journal of STEM Education: Innovations and Research 11, 34-60 (2010).

23 Davies, J. W. \& Rutherford, U. Learning from Fellow Engineering Students Who Have Current Professional Experience. European Journal of Engineering Education 37, 354365 (2012).

24 Ulijn, J. M., O'Duill, M. \& Robertson, S. A. Teaching Business Plan Negotiation: Fostering Entrepreneurship among Business and Engineering Students. Business Communication Quarterly 67, 41-57 (2004).

25 Rouvrais, S. s. r. e.-b. f. et al. A mixed project-based learning framework: preparing and developing student competencies in a French Grande Ecole. European Journal of Engineering Education 31, 83-93, doi:10.1080/03043790500429500 (2006). 
26 Pierce, C. E., Gassman, S. L. \& Huffman, J. T. Environments for Fostering Effective Critical Thinking in Geotechnical Engineering Education (Geo-EFFECTs). European Journal of Engineering Education 38, 281-299 (2013).

27 Welch, K. C., Hieb, J. \& Graham, J. A Systematic Approach to Teaching Critical Thinking Skills to Electrical and Computer Engineering Undergraduates. American Journal of Engineering Education 6, 113-123 (2015).

28 Strong, D. S. s. q. c. An Approach for Improving Design and Innovation Skills in Engineering Education: The Multidisciplinary Design Stream. International Journal of Engineering Education 28, 339-348 (2012).

29 Weilerstein, P., Ruiz, F. \& Gorman, M. The NCIIA: turning students into inventors and entrepreneurs. IEEE Antennas and Propagation Magazine 45, 130-134 (2003).

30 Heylen, C., Smet, M., Buelens, H. \& Sloten, J. V. Problem Solving and Engineering Design, Introducing Bachelor Students to Engineering Practice at K. U. Leuven. European Journal of Engineering Education 32, 375-386 (2007).

31 Waller, E. e. w. u. c. \& Kaye, M. H. Teaching problem-solving skills to nuclear engineering students. European Journal of Engineering Education 37, 331-342, doi:10.1080/03043797.2012.691871 (2012).

32 Shawcross, J. K. j. c. a. u. \& Ridgman, T. W. t. c. a. u. Manufacturing excellent engineers: skill development in a Masters programme. Engineering Education 7, 38-50 (2012).

33 Teng, S. G., Schreiner, S. \& Nelson, J. B. Teaching in the Factory: Connecting Industry to Engineering Education. Industry \& Higher Education 15, 353-359 (2001).

34 Flegg, J., Mallet, D. \& Lupton, M. Students' Perceptions of the Relevance of Mathematics in Engineering. International Journal of Mathematical Education in Science and Technology 43, 717-732 (2012).

35 Gainsburg, J. Learning to Model in Engineering. Mathematical Thinking and Learning: An International Journal 15, 259-290 (2013).

36 National Academy of Engineering, U. The engineer of 2020: visions of engineering in the new century. (National Academies Press Washington, DC, 2004). 